\title{
THE CONTROL OF PUPIL CONDUCT BY THE SCHOOL
}

\author{
M. R. Sumption*
}

The power of the school to control the conduct of pupils has its foundation in the concept known as "in loco parentis." The concept is well stated in Corpus Juris: ${ }^{1}$

As a general rule a school teacher, to a limited extent at least, stands in loco parentis to pupils under his charge and may exercise such powers of control, restraint, and correction over them as may be reasonably necessary to enable him properly to perform his duties as teacher and accomplish the purposes of education subject to such limitations and prohibitions as may be defined by legislative enactment. . . . If nothing unreasonable is demanded, he has the right to direct how and when each pupil shall attend to his appropriate duties and the manner in which a pupil shall demean himself.

The origin of this concept, both as a legal principle and a popular tradition, is not difficult to discover. Constitutional provisions of all states acknowledge the obligation of the state to provide and assure education for all citizens. In order to discharge this obligation, it is patently necessary for such an agency as the school, which is the formal institution set up for accomplishing this purpose, to have control over pupils. If it were not so, the school would be decidedly ineffective. One can easily imagine the confusion and anarchy of a school without control over pupil conduct. While there has been much legal action arising out of questions relative to the extent to which the school shall control pupil conduct, there is general agreement that this control is both necessary and desirable if the goal, so vital in a democracy, of an intelligent citizenry is to be achieved.

It should be kept in mind that the term "school" is used in the sense of an agenfy of the state. The control over pupils which the school may exert then is limited only by restraints which the law and the courts place on the controls which the government may legally exert over the individual. The school, being an agency of the state, and school districts creatures of the state, it follows that in the final analysis the power to control the pupil possessed by the school is part and parcel of the power of the state to control the acts of individuals. The metes and bounds of this power are, in our democracy, prescribed by the people through their legislative representatives and interpreted by their judicial authorities.

The topic of control of pupil conduct logically divides itself into two phasesnamely, control of pupil conduct on the school premises during school hours and control of pupil conduct off the school premises after school hours.

Two types of situations not covered in the above classifications immediately come to mind, to-wit: control of pupils on school premises after school hours and off

- Head, Office of Field Services, College of Education, University of Illinois.

${ }^{1}$ Control of Pttpils and Discipline, 56 C. J. \$1088 (1932). 
school premises during school hours. The first situation is covered by the general code applying to trespass wherein the pupil is regarded in the same light as any other person. In the second situation, the legal extent of pupil control may be regarded as the same as if on school premises provided that the pupil is engaged in school activity under the immediate authority and sponsorship of the school. For example, a group of pupils making a field trip to visit a factory or a park would be as fully within the legal control of the school as if the group were in the classroom. The pupil who is not so engaged and who is not under the immediate authority and sponsorship of the school falls within the classification "off the school premises after schools hours" even though school may be in session. In his case, since he is not in attendance at school for the day in question, such day is "after school hours," which refers to the time he last attended. In case of illegal absence, school control includes, of course, the power to cause the pupil to attend.

\section{Control of Pupils on School Premises During School Hours}

It is on the school premises, while school is in session, that the maximum degree of pupil control is practiced by the school. As has been previously stated, the teacher stands in the place of the parent while the pupil is in attendance at school. It may be well to point out the distinction between the duty and responsibility of the teacher who stands "in loco parentis" and the actual parent. In brief, the former has the duty and responsibility of exerting prudent control and direction over the pupil in all phases of his conduct, while in school, which directly affect his education and immediate welfare. The control of the parent is, of course, broader and includes responsibility not only for the child's immediate welfare but also for his long-range welfare. The distinction may be illustrated by the fact that, in the case of an acute attack of appendicitis, it would be the duty of the teacher to place the pupil under the care of a physician regardless of the wishes of the child. On the other hand, in cases such as the need for straightening a child's teeth or removing a disfiguring growth from his face, where immediate welfare is not involved, the responsibility and control is vested in the parent.

With this general distinction in mind, we may examine a series of situations which show the extent to which the control of pupil conduct has been held by the courts to be both necessary and legitimate. Added together this series should enable the reader fairly accurately to prescribe the boundaries and limitations within which the school exerts a legitimate control over the conduct of pupils in school.

Introductory to the series, however, a general statement relative to the legality of rules and regulations by the school designed to control the conduct of pupils is in order. First of all, to be valid, any such rules must be lawful and not in conflict with legislative statute. Second, they must be reasonable and not arbitrary in any way. Of course, it is necessary in cases where there is a difference of opinion as to what is reasonable for the courts to decide. However, courts are inclined to make interpretations which give broad discretionary powers to the school where the intent 
is to insure a wholesome atmosphere conducive to learning in the school. The series of topics which follows illustrates this attitude on the part of our courts.

\section{A. Saluting the Flag}

The practice of saluting the flag as part of the daily program of the school is not uncommon over the nation. The fact that the school has the legal right to include the practice in the educational program is not seriously questioned. However, the Supreme Court of the United States has ruled that participation shall not be enforced in the case of pupils whose religious faith makes the act of saluting the flag or the pledging of allegiance thereto a violation of their religious principles. In this ruling the Court pointed out: ${ }^{2}$

If there is any fixed star in our constitutional constellation, it is that no official, high or petty, can prescribe what shall be orthodox in politics, nationalism, religion, or other matters of opinion or force citizens to confess by word or act their faith therein.

The above case overrules a number of state court decisions as well as a previous Supreme Court ruling in 1940 in Minersville School District v. Gobitis. ${ }^{3}$ In these previous cases, the courts had held that forced participation in patriotic ceremonies was justified in as much as the state has the right, in the interest of its own safety, to engender and maintain patriotism among its citizens. The courts interpreted the salute and pledge as purely political without religious implications.

These points were so seriously questioned in the ruling case that they lose their validity. In the first place, is there any evidence to show that forced participation "engenders and maintains" patriotism? The Supreme Court said "No." Can anyone other than the individual himself determine with a free conscience what is contrary to his religious principles and what is not? Again, the answer is "No." Therefore, to compel pupils to salute and pledge allegiance to the flag against their conscience "invades the sphere of intellect and spirit which it is the purpose of the First Amendment to our Constitution to reserve from all official control."4

It should be noted that this decision does not prevent the school from incorporating patriotic exercises in the school program nor does it excuse pupils from participation because of any superficial indisposition or any engagement in other activities at the time.

\section{B. Fraternities and Sororities}

The courts have uniformly upheld the right of the school to regulate and control social, as well as educational, organizations in the schools. Some states, by legislative enactment, have forbidden secret societies of any kind in the schools. The powers of the school, with or without specific legislative enactment, are broad and inclusive. Any rules affecting school organizations which are in the interest of maintaining a good and wholesome school atmosphere will be deemed reasonable and proper by the courts. In I945, a state law of Florida forbidding the establish-

${ }^{3}$ West Virginia State Board of Education v. Barnette, 319 U. S. 624,642 (1943).

${ }^{3}$ Minersville School District v. Gobitis, 310 U. S. 586 (1940).

319 U. S. at 642 . 
ment of secret societies in public schools or the solicitation of members on school premises, or the joining of such secret societies by pupils, was upheld by the courts. ${ }^{5}$

In 1952, the Supreme Court of Oregon upheld the right of the Board of Education of Portland, acting under authority of a statute forbidding fraternities and sororities in high schools, to suppress all high school organizations which the superintendent considered inimical to the best interests of the pupils and the schools. ${ }^{6}$ In this case, the court held further that it was legal to regulate those organizations permitted to exist by controlling admission to membership and discharge therefrom.

Thus, the school may regulate or eliminate as it sees fit; the educational welfare of the pupils is the paramount consideration. The extent of control which may be practiced outside school hours is discussed later under the general topic "Control of Pupils Outside the School."

\section{Pupil Participation in Athletics}

The extent of control of pupils by the school with respect to participation in school-sponsored competition is clear. A pupil may participate at the pleasure of school authorities. He has no right to participation. It is a privilege extended by the school and may be withdrawn at the discretion of school authorities. On the other hand, a pupil may not be forced against his will to play on any athletic team or participate in any athletic exercises not included as a regular part of the physical education program.

The courts have gone so far as to uphold the suspension or expulsion of pupils who, contrary to school regulations, play on teams purporting to represent their school, even though such violation takes place off the school premises and during non-school time.?

\section{Control of Pupil Dress}

The school has the power to regulate the manner of dress of its pupils within reason. It may require the wearing of uniforms furnished by the school for particular activities or on special occasions. Girls may be forbidden to wear shorts or any attire deemed immodest or in poor taste by school authorities. Boys may be denied the privilege of wearing cowboy boots to school.

School officials may forbid the wearing of articles of dress which make unnecessary noise such as spurs, bell-like earrings and jangling ornaments, or squeaky shoes. They may also forbid the wearing of any attachment or device such as metal shoe plates which may damage the floors, walls, or stairs of the schools. Any article of dress which disturbs the school or damages school property may be forbidden and refusal to comply is a lawful reason to expel the guilty party. ${ }^{8}$

What was regarded as a reasonable rule regarding dress several decades ago might not be so regarded today. For example, a court ruling upholding a regulation

${ }^{5}$ Satan Fraternity v. Board of Public Instruction for Dade County, 156 Fla. 222, 22 So. 2 d 892 (1945).

'Burkitt v. School District No. I, I95 Ore. 471, 246 P. 2d 566 (1952).

Tinzer v. Directors of Independent School District of Marion, 129 Iowa 44I, I05 N. W. 696 (1906).

${ }^{B}$ Stromberg v. French, 60 N. D. 750, 230 N. W. 477 (1931). 
of an Arkansas board forbidding pupils the use of cosmetics would hardly be considered reasonable by a modern court. ${ }^{\circ}$

Suffice it to say when any pupil dress is immodest, offensive to good taste, or for any reason inimical to the best interest of the school, such dress may be forbidden; and, if the situation is not remedied, the pupil may be expelled.

\section{E. Confinement of Pupils to School Grounds}

Once the pupil arrives on the school grounds, he comes under the jurisdiction of school authorities for the school day. Pupils may, therefore, be required to remain on the school grounds throughout the day, providing the necessities and conveniences of life are available thereon. The fact that a pupil prefers to eat at a restaurant does not excuse him from obeying a regulation requiring pupils to remain on the school grounds all day, if hot lunches are provided at the school. ${ }^{10}$

Since the school is responsible for the pupil during school hours, it follows that pupils may be required to remain on the premises throughout the day or, in cases of inclement weather, be confined to the building itself. ${ }^{11}$

\section{F. General Misconduct in School}

There are many forms of misconduct which ingenious mischief makers have devised to annoy teachers, worry administrators, circumvent rules, and disturb the general welfare of the school. School authorities are given broad discretion in the control of this type of behavior in pupils. The rights of school officials as expounded in the courts are illustrated in a number of cases.

If a pupil persists in whispering, causing disorder in the classrooms, being rude to teachers, slovenly in work habits, fighting on the school grounds, or conducting himself in such a way as to endanger other pupils, school officials may expel him. Low mentality of the pupil is no excuse. In I893, the Supreme Court of Massachusetts firmly established this prerogative and subsequent court decisions have confirmed it. ${ }^{12}$

Whether certain acts of disorder so seriously interfere with the school that one who persists in them, either voluntarily or by reason of imbecility, should not be permitted to continue in the school, is a question which the statute makes it their [the school board] duty to answer: and if they answer honestly, in an effort to do their duty, a jury composed of men of no special fitness to decide educational questions should not be permitted to say that their answer is wrong.

School authorities have the right to insist that a pupil who has knowledge of another pupil's misconduct shall give them the information. Failure by one pupil to reveal to authorities the name of a fellow pupil who has committed a serious infraction of school regulations is grounds for expulsion.

\footnotetext{
${ }^{9}$ Pugsley v. Sellmeyer, 158 Ark. 247, 250 S. W. 538 (1923).

${ }^{10}$ Flory v. Smith, I45 Va. $164, x_{34}$ S. E. 360 (x926).

${ }^{11}$ Christian v. Jones, 211 Ala. 16I, 100 So. 99 (1924).

12 Watson v. City of Cambridge, I57 Mass. 56r, 563,32 N. E. 864,865 (1893).
} 
The ordinary laws of decency and propriety in conduct and in speech can not be disregarded and when broken there must be prompt and effective punishment, otherwise the great objects of the school will fail of accomplishment. . . . It is the duty of all good citizens to uphold the officers of the law and when called upon by a grand jury every man may be required to state upon oath what he may know as to the perpetration of any crime or misdemeanor, though he is, of course, not bound to criminate himself.

So here every pupil, when called upon by the superintendent or by the board, should, as a matter of duty and loyalty to what is essential to the common welfare, freely state anything within his knowledge not self-criminating, that will assist in bringing the offender to justice and thereby tend to the repression of all such offences.

If he refuses to do this he is guilty of disobedience, for which reasonable punishment may be inflicted. By the provisions of the school law . . . the board may suspend or expel a pupil for "gross disobedience or misconduct." ${ }^{33}$

It should be pointed out also that there are generally recognized standards of acceptable conduct on the part of pupils, and school authorities have the legal right to insist that they be met. It is not necessary that specific rules or regulations be violated in order lawfully to discipline a pupil. Physical punishment and even expulsion from school are justified as corrective measures to uphold this standard of conduct.

\section{Control of Pupils Outside the School}

The dividing line between parental and school control of pupils after school hours and off school premises is not clearly marked. It appears to be more or less in a legal twilight zone. Particularly is this true in the matter of pupil behavior and routing on the way to and from school.

Two general principles which are helpful guides have, however, been rather consistently followed by the courts. The first is that any act of a pupil detrimental to the orderly discipline or well-being of the school, regardless of where committed, is of legitimate concern to the school. The second is that the school has prohibitory and punitive power over the acts of pupils which interfere with their school work or with other pupils, or reflect on the reputation of the school.

The first principle, that of legitimate concern, is necessary because a school is an integral part of the community, not an isolated institution. Its pupils are citizens of the community. The influence for good which a school exerts in a community is in no small measure dependent on good public relations and good morale among pupils and teachers. Such favorable conditions are, in turn, dependent in many. aspects upon the conduct of pupils outside the school.

The second principle is a corollary to the first. School authorities are privileged to make rules and regulations to prohibit such action by pupils outside the school which may reasonably be shown to interfere with school work, impair discipline, or bring into disrepute the school, its officials, or its teachers. The power is prohibitory in nature and does not extend to positive acts requiring pupils to perform tasks at

\footnotetext{
${ }^{23}$ Board of Education v. Helston, 32 Ill. App. 300, 305-306 (I889).
} 
home such as studying at designated hours or attending school-sponsored evening events or public lectures. ${ }^{14}$ For example, school authorities have the power to forbid pupils to attend late movies but not the power to require them to attend an evening musical concert.

The test of any school regulation is its reasonableness as to its effect both on the school and on the pupil. The term reasonableness as here used includes a connotation of "needed" or "needful." The courts have upheld the reasonableness of a rule forbidding attendance at movies on evenings preceding school days because it was reasonable to assume, and could doubtless be demonstrated, that such attendance left the pupil sleepy and impaired his work in school. ${ }^{15}$ In this case, it is not difficult to see that the offense ruled against was detrimental to both school and pupil. There is, however, yet another aspect of the reasonableness test, namely, the extent of invasion of what ordinarily is parental domain. How far can the school reasonably go in regulating pupil conduct without conflicting with parental control?

A number of cases are here cited and briefly discussed to give the reader a fairly clear idea of the legal framework within which the school controls the conduct of pupils outside the school.

In the case of secret societies, the fact that their activities are carried on elsewhere than at school does not prevent school officials from forbidding pupils to hold membership. However, it should be noted that this holds good only during the school term and does not embrace the vacation period. At that time, says the court, parental authority has full sway in the matter. ${ }^{16}$

The fact that athletic team contests are conducted after school hours and away from school premises does not free them from school control if either team represents or purports to represent the school. ${ }^{17}$

Behavior of pupils outside the school involving profanity, drunkenness, immorality, viciousness, or defamation is ample reason for school officials to punish or expel the guilty parties. The courts have uniformly upheld their right to deal with such cases in the manner mentioned. ${ }^{18}$

Ridicule of teachers or school officials by word or deed is subject to corrective action by the school. Neither time nor place is a determining factor if the school is brought into disrepute. ${ }^{19}$

The school has nominal control over pupils on their way to and from school. School officials may insist that pupils go directly from school to home when they are dismissed..$^{20}$ Where transportation is furnished, pupils may be required to go home on the bus even though they prefer to walk or ride with another pupil. However, should a parent call for his child, the law would tend to support the right of the

\footnotetext{
${ }^{14}$ Hobbs v. Germany, 94 Miss. 469, 49 So. 515 (1910).

${ }^{15}$ Mangum v. Keith, 147 Ga. 605, 95 S. E. 7 (I918).

${ }^{10}$ Wilson v. Abilene Independent School District, r90 S.W.2d 406 (Tex. Civ. App. 1945).

${ }^{27}$ Sce note 7, stupra.

${ }^{28}$ Douglas v. Campbell, 89 Ark. 254, II6 S. W. 211 (Ig09).

19 Lander v. Seaver, 32 Vt. 144 (I9Io).

${ }^{20}$ Jones v. Cody, 132 Mich. I3, 92 N. W. 495 (Ig02).
} 
parent to take the child home in whatsoever manner he chose. For school officials to insist that the child go directly home by bus would, in such a situation, doubtless be overreaching their authority. When the parent assumes responsibility for the child, it is presumed that the latter has reached "home" in the legal sense.

Reasonable exceptions to a school rule that pupils go directly home would probably be recognized by the courts. For example, if the parent directed the child to stop at a store on the way home or to post a letter on his way to school, even though this would involve his going out of the way, the parent's right to so control would likely be upheld.

The route which the pupil takes when he walks to and from school is generally held to be under the direction of the parent. However, should it be established that the route subjected the pupil to evil influences such as gambling houses or taverns or undue hazards, it would doubtless be within the power of the school to change the route in the interest of the pupil's well-being and safety.

Any misconduct of pupils on the way to and from school falls under the discipline of the school. The fact that one or more pupils engaged in misconduct have been home does not alter the case.

Supposing that some strong-armed juvenile bully attending school lived upon the next block and sought for a brief moment the asylum of his home, and then sallied forth and beat, abused, and terrorized his fellow pupils as they passed by returning home; then by the claim urged by plaintiff he would be immune from punishment by the school authorities, while if he began his assaults before he had passed within the bounds of his own front yard he would be liable to proper punishment for any harm done. Now the harm done to the morale of the school is the same. The injured and frightened pupils are dismayed and discouraged in going to and coming from the school, and demoralized while in attendance. It will not do to say, as plaintiff's counsel argue, that the proper resort to correct such an abuse is the parents of such offenders, or the public prosecutors. Some parents would dismiss the matter by saying that they could give no attention to children's quarrels; many would champion their children as being all right in their conduct. The public authorities would very properly say, unless the offense resulted in quite serious injury, that such affrays were too trifling to deserve their attention. Yet the harm to the school has been done, and its proper conduct and operation seriously harmed, by such acts. Correction will usually be sought in vain at the hands of parents; it can only be successfully applied by the teacher..$^{21}$

The rules of the school regarding pupil conduct may be extended to cover the pupil while he is on his way to and from school. For example, a school rule against smoking might be extended to include the homeward journey, and it would doubtless be upheld even though it would be difficult to enforce. The practicability of the rule would not be an issue-only the reasonableness of it.

Perhaps the broad outlines of the framework of law within which the school controls the conduct of pupils outside the school may be best set forth in the words of two court decisions. The first indicates the breadth and depth of this framework, and the second its limitations.

${ }^{21}$ O'Rourke v. Walker, ro2 Conn. 130, 136, 128 Atl. 25, 26-27 (1925). 
Any rule of the school, not subversive of the rights of the children or parents, or in conflict with humanity and the precepts of divine law, which tends to advance the object of the law in establishing public schools, must be considered reasonable and proper. If the effects of acts done out of school-houses reach within the schoolroom during school hours and are detrimental to good order and the best interest of pupils, it is evident that such acts may be forbidden. . . .22

School boards and boards of education have important duties to discharge, and we have no disposition .... to circumscribe their powers in too narrow a compass. The statute clothes them with power to make all needful rules for the government of the school established within their respective jurisdiction, and to suspend any pupil from the privileges of the school for non-compliance with the rules established by them, or by the teacher with their consent . . . yet it cannot fairly be claimed that the boards are uncontrolled in the exercise of their discretion and judgment upon the subject. The rules and regulations made must be reasonable and proper, or, in the language of the statute, "needful," for the government, good order, and efficiency of the schools-such as will best advance the pupils in their studies, tend to their education and mental improvement, and promote their interest and welfare. But the rules and regulations must relate to these objects. The boards are not at liberty to adopt rules relating to other subjects according to their humor. ... ${ }^{23}$

\section{Enforcement of School Regulations}

The control of pupils is possible only when effective means of enforcing rules and regulations are available to the school. There are three general types of punishment meted out to pupils by school authorities as the result of infractions of school regulations. They are, in an ascending order of severity, detention at noon, recess or after school; corporal punishment; and suspension or expulsion. All have been upheld by the courts when carried out under proper conditions and with reasonable care and discretion. Although there are numerous variations in pupil punishments, most corrective actions will fall under one of these three heads.

Detention of the pupil at times when he is ordinarily free for recreational activities or after school hours when other pupils are dismissed is perhaps the most common form of corrective action. No question is raised regarding the right of the school to detain pupils during school hours; however, detention after school hours has been the subject of some litigation. The right of the school so to detain a pupil has been upheld. ${ }^{24}$ In cases where the pupil is transported by bus, however, it would seem the courts might question the reasonableness of this particular form of punishment.

Corporal punishment as a means of maintaining control over the pupil is not nearly as prevalent as it once was. However, only one state, New Jersey, and the District of Columbia forbid such punishment by statute. One state, West Virginia, does not include it in a list of punishments specifically approved by statute. The remaining states leave the matter to the discretion of local school authorities. Almost all states have specific laws forbidding cruelty to children, and school authorities are

${ }^{22}$ Burdick v. Babcock, 31 Iowa 562, 565 (1871).

${ }^{23}$ State ex rel. Powe v. Board of Education, 63 Wis. $234,237,23$ N. W. 102, 103-104 (1885).

${ }^{2}$ Fertich v. Michener, II I Ind. 472, II N. E. 605 (1887). 
obligated to make sure that punishment is reasonably proper. If such is not the case, the person administering the punishment is liable on a charge of cruelty to a child or assault and battery.

When is corporal punishment reasonable and proper? The following characteristics of reasonable and proper punishment are offered as guides:

I. It is in conformance with statutory enactments.

2. It is for the purpose of correction and without malice.

3. The pupil knows wherein he has erred and is thus aware of the reason for the punishment.

4. It is not cruel nor excessive and leaves no permanent mark or injury.

5. It is suited to the age and sex of the pupil.

6. It is administered in the pupil-teacher relationship.

School authorities must be aware of statutory enactments which may define the limits of corporal punishment of children or even forbid it entirely. It is elementary, of course, that any punishment must be in the spirit of correction, never with malice. If malice can be proven, the person administering the punishment is, in most states, subject to a heavy fine, imprisonment, or both.

The pupil must know for what he is being punished; else he would not know in what respect to mend his ways. The principal justification for punishment is the correction of the child; therefore, he must be aware of the error or violation for which he is chastised.

Physical punishment, which would be suitable for a boy of sixteen, might be totally unsuited for a girl of the same age. Likewise, a six-year-old child should receive a much lighter punishment than one of fifteen, other things being equal.

A teacher punishing a pupil for conduct during a semi-professional baseball game in which both were players would find himself liable to prosecution. The teacherpupil relationship is essential to proper and reasonable punishment.

All punishment must be moderate and merciful with due care exercised that no permanent marks or injuries to the person result.

The third type of punishment is relatively seldom used and represents a last resort in the control of the pupil. Suspension is the term generally applied to a temporary barring of the pupil from school, and expulsion to a more permanent action. Suspension usually implies that final judgment is held in abeyance until facts are studied or authorities take official action. Such action may be either expulsion or reinstatement. Suspension is generally an act of the professional school staff while expulsion is a prerogative of the board of education. The expulsion of pupils has been the subject of much litigation over the years. The legal right of the board to expel a pupil is firmly established, but the reasonableness of such action is often challenged. It is not the right to expel but the reason for so doing which is frequently the subject of litigation. 
Conclusion

In conclusion, it may be said that the over-all legal framework within which the school controls its pupils is based on the principle that education is a benefaction of the state for the sake of which individuals must sacrifice a measure of personal freedom in order to assure the maximum usefulness and effectiveness of the educational system. The touchstone question is, "Does it affect the welfare of the school?" If the answer is in the affirmative, then the school has a legal right to be concerned and, in cases where the effect is deleterious, to take reasonable action to protect and maintain the well-being of the institution. As has been shown, the concern of school authorities is not confined to school hours or the school premises, but embraces the community and even beyond. The acts of pupils, regardless of when or where they are committed, are the proper concern of school officials if they directly affect the welfare of the school. 